\title{
Group Behavior in Social Media: Antecedents of Initial Trust Formation
}

\author{
Mahmud A. Shareef \\ School of Business \& Economics, North South University, Bangladesh \\ Email: mahmud_akh@yahoo.com \\ Kawaljeet K. Kapoor \\ Aston Business School, Aston University, UK \\ Email: kawalkap@gmail.com
}

Bhasker Mukerji

St. Francis Xavier University, Antigonish, Nova Scotia, Canada

Email: bmukerji@stfx.ca

Rohita Dwivedi

Prin LN Welingkar Institute of Management Development and Research, Mumbai, India

Email: rohita.dwivedi@welingkar.org

Yogesh K. Dwivedi

Emerging Markets Research Centre (EMaRC), School of Management

Swansea University Bay Campus, UK

Email: ykdwivedi@gmail.com

\begin{abstract}
This study investigates the influence of antecedents of user trust amongst peers on social media platforms that they apply without sufficient cognitive judgment. Based on extensive literature review and analysis of social theories, we propose a theoretical framework for social media trust (SMT). Based on the SMT model, we conduct empirical analysis using structural equation modeling to verify the cause-effect relationships hypothesized in this study. The findings reveal that initial formation of SMT relies on five predictors - fulfilled expectations, predictability, familiarity, monitor, and norms. These findings have significant theoretical and practical implications. The study finds that peers are likely to invest blind faith in the content shared on social media groups without subjecting it to verification. It also identifies the threat of biased
\end{abstract}


peers, who spread irresponsible content with predetermined motives to influence members of certain social media groups. Policymakers can use insights from this study to highlight the ills of non-verification, and its potential to cause harm at the very extreme.

Keywords: Social media, trust, group behavior, affective attitude, social behavior

\section{Introduction}

In most developing countries, creating, sharing, and circulating information through social media networks is extremely popular (Aladwani \& Dwivedi, 2018; Cao \& Yu, 2019; Dwivedi et al., 2018a; Kizgin et al., 2019; Misirlis \& Vlachopoulou, 2018; Olanrewaju et al., 2020; Shareef et al., 2016; Shin, 2013; Zhang et al., 2019). Citizens in developing countries find such platforms to be dynamic, robust, quicker, and easier to share views (personal, social, organizational, political, and commercial) within their network to pursue unified doctrines (Haciyakupoglu \& Zhang, 2015). Recent events suggest that social media users do not analyze, investigate, and/or validate sources of the content they share with their network members/peers. For instance, in July 2018, after two students were killed in Bangladesh in a reckless road accident, some students initiated a social movement to regularize the traffic system. Some political activists took advantage of this situation and created false propaganda on social media platforms to instigate young people against the government, creating unrest in Bangladesh (The Daily Star, 2018). Many young Facebook users actively shared and liked the above content without verifying its authenticity. Such trust in shared content without verification is a prominent trait of social media peers (Habibi et al., 2014). Yet, literature on neither trust nor social media has investigated this potential issue. To address this significant gap, our study attempts to explore and identify how initial trust formation occurs amongst social media peers. We investigate this overarching issue via a thoroughly designed experiment and survey.

Over the last 60 years, marketing researchers (Fishbein, 1963; Mitchell \& Olson, 1981; Ho \& Dempsey, 2010; Molins-Ruano et al., 2016) have analyzed consumer behavior to understand the factors influencing consumer opinions towards a product/service. The theory on consumer attitudinal change suggests that negative attitude towards a product can be altered. Behavioral theorists (Fishbein \& Ajzen, 1975; Bandura, 2002) suggest that human beings learn from their external environment. When they experience transformation of a negative attribute to a positive one, their ultimate perception is that all negative aspects associated with a given product/service

have been removed. This social learning from external environment, where any single attribute change confirms customers' overall perception change, is very similar to social group behavior. This is explained by the social identity theory (Hogg, 2003), and social media behavior can be evaluated using such group behavior concept.

Research on social media marketing asserts that peers in any social media group have synchronized perceptions of shared content, as they share common interests and compatible personalities (Eltantawy \& Wiest, 2011; Ems, 2014; Haciyakupoglu \& Zhang, 2015; Shareref et 
al., 2018a; Shin, 2013). Social penetration theory (Altman \& Taylor, 1973) suggests that sharing information within a social network is based on shared views of its members to become social peers. It can thereby be argued that members of the same social media group express similar trustworthiness behavior (Ems, 2014; Haciyakupoglu \& Zhang, 2015; Lee \& Chan, 2015; Shin, 2010). Theory of reasoned action (TRA) (Fishbein \& Ajzen, 1975) and theory of planned behavior (TPB) (Ajzen, 1991) support this idea by suggesting - social associations i.e. 'subjective norms' significantly influence user behavior.

Peers of any Facebook group share similar perceptual beliefs and self-concept (Dwivedi et al., 2018a; Eltantawy \& Wiest, 2011; Ems, 2014). Therefore, when members of a social media group create and share content, the peers of that group develop synchronized affinity towards such content (French, 2017; Shareef et al., 2019). They add personalized views to that content and willingly share/circulate it amongst other peers of that group without self-regulation. The validity and/or authenticity of such content is unquestioned because a member belonging to a group they trust originally shared the content. The psychological essence of complementarity theory suggests that given the cultural integrity, users of any social media group perceive content derived from their peers as encouraging complementary content (Fiske, 2000; Shareef et al., 2013). Furthermore, socio-technical theory (Damodaran et al., 2005) suggests that infiltration of technology into social orientation imparts new behaviors, which are collective and separated from individual attitude towards technology and individual social behavior. Thus, social media behavior can be characterized by new dimensions of integrity, dedication, and consensus, which are derived from technology, society, and organization. Thus, social media marketing is stronger than reasonably expected in sharing and forming pre-directed intentions and opinions.

Therefore, we aim to understand the antecedents of trust on social media platforms, and their influence on content sharing without applying sufficient cognitive judgment. In doing so, we raise the following research questions: (a) Do social media users trust all messages circulating within their network without verifying the source and sender intentions? (b) How do social media users develop trust towards peers, who post and circulate messages within their network? Such understanding is critical, as false content on social media can trigger political agitation and social unrest (Eltantawy \& Wiest, 2011; Ems, 2014; Haciyakupoglu \& Zhang, 2015; Lee \& Chan, 2015). The topics of social media promotion, viral marketing, and consumer behavior have been widely investigated in recent marketing literature (Akar \& Topcu, 2011; Habibi et al., 2014; Shareef et al., 2019; Shin, 2010). Yet, very few researchers have explored the concept of trustworthiness (Barnes \& Mattson, 2009; Ho \& Dempsey, 2010; Kim \& Ko, 2012; Shin, 2010). In controlling the development of perceptual belief, theorizing the antecedents of trust on social media is becoming an issue for social scientists and marketing researchers (Haciyakupoglu \& Zhang, 2015; Lee \& Chan, 2015). Understanding of synchronized trusting behavior on social media platforms can prevent the spread of unreliable content, and contribute to the existing literature on trust, consumer behavior, emerging markets, and social media promotion. 
In the next section, we review theoretical issues of social media marketing, attitude formation, and trust development behavior. We then propose a theoretical framework and formulate appropriate hypotheses. Research methodology and data collection are explained next, followed by statistical analysis of the gathered data. Findings, discussions, and implications are then presented alongside limitations and future research avenues.

\section{Theoretical background}

\subsection{Social Media Marketing}

Social media marketing has caught momentum in the recent years and marketing managers are now allocating enough time and resources to build on its benefits (Dwivedi et al., 2015; See-To \& Ho, 2014). Traditional marketing strategists struggle to capture consumer attention with promotional offers (Chu, 2011). Due to changing lifestyles, behaviors, and psychological and commercial statuses, consumers do not deliberate over promotional messages communicated via traditional advertisements (Shareef et al., 2019). Without exposure to advertisements, favorable consumer attitudes are difficult to achieve. Here, social media platforms, which fundamentally are social interaction hubs, present promising opportunities to communicate with the consumers (Alalwan et al., 2017; Eltantawy \& Wiest, 2011; Ems, 2014; Shareef et al., 2016; Kapoor et al., 2018). Psychological behavior of consumers on social media platforms suggests that they are exposed to multidisciplinary issues related to their individual, social, national, and commercial life on a daily basis (French, 2017). They enthusiastically allocate daily time to provide opinions and share experiences on social media (Eltantawy \& Wiest, 2011; Haciyakupoglu \& Zhang, 2015). They blindly accept content shared by members of their social group, as they share identical psychological sentiment and behavior with them (Schaik et al., 2011; Shareef et al., 2019). Behavioral learning theory (Bloch \& Marsha, 1983; Ertmer \& Newby, 1993; Nord and Peter, 1980) suggests, consumers learn from external messages. We can assume such external messages to be the information created and shared by peers of a social media network.

Such social interaction medium gives marketers a new platform for persuading consumers to learn about their products and services; in some cases, members of social media groups can utilize this opportunity to infiltrate certain preformed unfavorable notions about such marketers (Eltantawy \& Wiest, 2011; Ems, 2014; Haciyakupoglu \& Zhang, 2015; Lee \& Chan, 2015). As explained earlier, spreading baseless notions on such platforms can negatively influence several user opinions, and in some extreme cases, create unrest. In summary, subversive sharing of predirected opinions can have detrimental effects on society and market economy.

\subsection{Behavior and Attitude}

Consumers' behavioral attitude is composed of marketing, social, and individual traits (Bagozzi et al., 2012). Traditionally, attitude is cognitive, affective, and conative. Contrasting to the discourse of TRA, people are motivated to form attitudes based on own beliefs, reflecting selfconcept and personality, which here is assumed to be aligned with the peers interacting on a 
social media group. On the other hand, both attitude and influence of socially associated people act simultaneously in affecting behavioral intentions, ultimately leading to actual behavior (Eltantawy \& Wiest, 2011; Ems, 2014). It can thereby be argued that in any social media group, peers have identical attitudes and they act as subjective norms; thus, creating, publishing, and sharing information by liking content on social media is much easier than on any other promotional hub (Shareef et al., 2018a; Shareef et al., 2019).

Proponents of social learning theory (Bandura, 1963; Bandura, 2002; Schaik et al., 2011; Skinner, 1957) acknowledge that psychologically, people are more biased to learn from social interactions, which are compatible with their own intentions, judgment, and attitude towards life. Since social media group members have congruent attitudes, they are inspired to share opinions by learning from messages shared by other group members (Eltantawy \& Wiest, 2011; Lee \& Chan, 2015), without verifying every message. This way, any message on a social media group picks momentum, resulting in the construction of group opinions stemming from common behaviors and attitudes of the group peers (Anderson \& Bushman, 2001; Paik \& Comstock, 1994). In this social learning hub, trustworthiness is a self-concept, which is developed willingly and spontaneously in forming favorable cognitive attitudes towards shared content (Haciyakupoglu \& Zhang, 2015; Hughes, 2011; Lee \& Chan, 2015). Here, observational learning theory (Bandura, 1963) based on social learning supports such psychological behavior.

\subsection{Trust Model}

Trust is a complex human behavior, composed of and influenced by multidimensional parameters (Dion, 2000; Floyd, 2011; Haciyakupoglu \& Zhang, 2015; Gefen \& Straub, 2004; Shareef et al., 2016; Shin, 2010). From the social interaction perspective, trust is an issue of gradual progression, and is formed when one has confidence in the actions of a person, suggesting they are reliable. It is an outcome of relying willingly on an exchange partner (Moorman et al., 1992). Synthesizing literature on different trust models (Anderson et al., 2008; Gefen et al., 2003; Pavlou, 2003; Shareef \& Kumar, 2012), Shareef et al. (2018) developed a conceptual paradigm of trust, reflecting the idea of expected reliability from interactions. By organizing the central idea of trust in the context of social media, it can be deduced as the overall confidence a person has in their own cognitive, affective, and behavioral attitude towards another socially associated individual's actions to be aligned with their expectations (Gefen \& Straub, 2004; Schaik et al., 2011). In social media, trusting peers is an automatic belief that their actions, i.e. shared content/information on social networks are reliable and consistent with favorable expectations (Shareef et al., 2018). Researchers suggest that for any social interaction involving remote technology, for instance - computer mediated interactions, both external and internal environments impact interpersonal trust (Goles et al., 2009; Li et al., 2008; Shin, 2009).

Researchers analyzing trust reveal different paradigms of trustworthiness, parties to be trusted, and social interactions that may lead to trusting behavior (Gefen, 2002; Jarvenpaa et al., 2000; Mukherjee \& Nath, 2003; Shareef et al., 2008). Staples et al. (1998) find trust is developed 
gradually and depends on cognitive and affective components of attitude. Initial formation of trust is substantially related to familiarity and reputation (Shareef et al., 2008). Gradual development of trust on social media may arise from experience of social interactions with peers. By using the socio-technical lens (McAllister, 1995), it can be suggested that trust formation is directly related to the psychological status and compatibility between members of a social media group. However, since trust is multidimensional and dependent on personality, social orientation, organizational behavior, and market paradigm, it is complex to identify the antecedents of trust formation between socially associated members (Mayer et al., 1995).

\section{Conceptual model and hypotheses development}

We base our theoretical framework on the following premise - in trusting peers of a social media group, the expectation is that there are no preformed motives or personal gains for members who circulate content in that group (Shareef et al., 2018a). Trusting such content is governed by affective component of attitude; in addition, cognitive component of attitude derived from experience of interacting with social network peers also contributes to trust formation (Shareef et al., 2018a). This cognitive component is shaped by interactions between peers, who demonstrate identical beliefs and consensus towards social incidents (McKnight et al., 2002; Schaik et al., 2011). They adhere to ethical standards (Hosmer, 1995), maintain neutral and responsible behavior (Zucker, 1986), uphold societal commitment (Luhmann, 1979), and are without any self-interest (Ho \& Dempsey, 2010).

\subsection{Dependability (DD) and Fulfilled Expectations (FE)}

Social psychologists postulate that the need-satisfaction process motivates trust (Butler, 1991; Jarvenpaa \& Tractinsky, 1999; Shareef et al., 2018b). According to Maslow's hierarchy of need theory (Maslow, 1943), people become frustrated when they cannot find conclusive ways to fulfill certain deficiencies. Evidence from social exchange theory (SET) (Thibaut \& Kelley, 2008) and Mcleland's need theory (McClelland, 1988) suggests that strong desire for fulfilling needs motivates users to engage with peers capable of pursuing speculations that fulfill those deficiencies. In social media interactions, users eagerly share and support peer views, which can fulfill, or at least supplement their needs without them having to deliberate over the validity of such content (Gefen, 2002; McKnight et al., 2002). This intrinsic motivation and feeling of compatibility with their group peers of identical social status can lead to trust formation (French, 2017). From literature on trust (Ganesan, 1994; Giffin, 1967; Jarvenpaa \& Tractinsky, 1999; McAllister, 1995), we shortlist two constructs - dependability (personal deficiency) and fulfilled expectation (social deficiency) to measure needs-based trust.

Based on collective understanding (Pavlou, 2003; Rotter, 1980; Schurr \& Ozanne, 1985), we define dependability as the perception of psychological confidence in social agents derived from intrinsic need to satisfy one's own deficiency. Researchers on social behavior (Kim, 2016; Shareef et al., 2018b; Shin, 2010) find that psychologically, people trust those who have similar 
behavior as them, so they can develop dependability. Dependence is crucial when a user feels deficient in their ability to fulfill a personal need. Proponents of SET also certify that psychological dependence in the search for meeting personal deficiencies is key for developing trustworthiness behavior.

From literature based on trust (Butler, 1991; Ganesan, 1994; Giffin, 1967; Jarvenpaa \& Tractinsky, 1999), we define fulfilled expectations as the assurance that a social media group member has the capacity, integrity, and ability to overcome social deficiencies via their contributions on social media. People have different expectations from society, and they invest varying degrees of effort to fulfill these expectations (Butler, 1991; Ganesan, 1994). Therefore, when they find a peer in their social media group with similar views and social commitment, they become interested in sharing and supporting their peer's content without any cognitive dissonance. There is a spontaneous sense of belonging and benevolence amongst members of such groups (Shareef et al., 2019). This streamlines a long preserved urge of the group members

to contribute ethical values to the society, and they believe that all of their group members have similar integrity (Jarvenpaa \& Tractinsky, 1999; Morgan \& Hunt, 1994) and ability (Rotter, 1980; Schurr et al., 1985) to initiate and diffuse such sentiment. Researchers in human psychology recognize this trait as - fulfilled expectations.

Therefore, this study proposes the following hypotheses,

$\mathrm{H}_{1}$ : Need-based dependability contributes towards initial trust development

$\mathrm{H}_{2}$ : Need-based fulfilled expectations contribute towards initial trust development

\subsection{Familiarity (FM) and Credibility $(C R)$}

People, as free agents of the society, have complicated psychological status and do not behave rationally, or make decisions with predictable social judgment (Angeli et al., 2016; Kumar et al., 1995; Williamson, 1993). It is complicated when virtual technology seamlessly governs social environment through social media. Therefore, it is important to understand why peers on social media trust each other without questioning the validity of shared content. Typically, rules and regulations have enormous impact on controlling physical institutions, but social media is virtual, where a group of people with unified doctrines and expectations from society interact in the hope of developing group perceptions, uncontrolled by external regulations (Gefen \& Straub, 2004; Hosmer, 1995). As a result, attitude of disposing trust controls social media behavior (Butler, 1991; Ganesan, 1994; Gefen, 2000; Kumar, 1996) based on familiarity and credibility of social media peers. Drawing from the literature on trust (Fukuyama, 1995; Gefen, 2000; Gefen et al., 2003; Mukherjee \& Nath, 2003), we define knowledge-based familiarity as the collective evaluation and established perception about peers of a social media group, based on relationships developed via social media interactions over time. 
Group members develop familiarity over a period of continuous interaction on social media, which reveals each member's personality, opinions, beliefs, and behaviors (Kumar et al., 1995). Such familiarity results in the development of virtual relationships, where in the absence of typical rules and regulations, a social understanding is established. This instills trustworthiness within the group (Gefen, 2000; Morgan \& Hunt, 1994). Familiarity, a behavioral component of trust, mostly governed by affective attitude, can reduce uncertainty (Fukuyama, 1995.). In any society, social relationships can eliminate uncertainty, as people find assurance and reliability in known relationships (Shareef et al., 2013). Therefore, familiarity is a driver of trust formation; research on social psychology and ICT (Korsgaard et al., 1995; Shareef et al., 2008) supports this view.

Familiarity also leads to psychological development of emotions, leading to fulfilled expectations (Gefen \& Straub, 2004). Based on SET, it can be argued that a familiar peer can fulfill expectations (Hogg, 2003). As theory of mind (Astington, 2003) suggests, in navigating social gaps and unsatisfactory situations, unfulfilled desires of human mind inherently support expected tasks of known people, who consistently correlate and supplement that person's inert intentions. That means, if there is any opportunity, human beings always try to fulfill own unfulfilled (inert) desires by other known people. Behavioral theories also support this view.

From literature based on trust (Butler, 1991; Ganesan, 1994; Kumar, 1996), we define credibility as the confidence in peers of a social media group that they will not intentionally fabricate facts, as they are free from social and commercial bias. Credibility of peers is also a knowledge-based construct developed via interactions on social media, where group members become acquainted with the philosophy of their peers and understand their commitment towards society (Shareef et al., 2019). Based on perceptions of authenticity of group members' activities, users assess if their peers are biased, or are capable of spreading content that can cause harm (McAllister, 1995). Researchers (Pennington, 2008; Schaik et al., 2011) confirm that interactions over a longer period instill reliability and trustworthiness, as peers become more confident of each other's intentions from experience.

We thus hypothesize the following relationships,

$\mathrm{H}_{3}$ : Knowledge-based familiarity contributes towards initial trust development

$\mathrm{H}_{3 a}$ : Knowledge-based familiarity contributes towards fulfilled expectations

$\mathrm{H}_{4}$ : Knowledge-based credibility contributes towards initial trust development

\subsection{Predictability $(P R)$ and Conformity $(C N)$}

When someone behaves as expected, their behavior reflects predictability (Frey \& Jegen, 2001). As per SET (Thibaut \& Kelley, 1959), expected behavior from involvement in the same social media group brings peers together to exchange trusted opinions on social occasions. This leads to 
relationship development between peers, triggering willful and spontaneous trust (Homans, 1961). Different researchers (Hogg, 2003; Li et al., 2008) argue that in social media interactions, members attempt to dispose trust in peers, as they can predict peer behaviours, and also find evidence that conforms to their predictions. This study thus defines two constructs, predictability and conformity for the development of initial trust. Drawing from the literature on trust formation (Hart \& Saunders, 1997; Hogg, 2003; Schurr \& Ozanne, 1985), this study defines predictability as the psychological assurance that members of a social media group will behave as expected. Social psychology researchers (Hart \& Saunders, 1997; Hogg, 2003; Li et al., 2008; Mayer et al., 1995; Wu et al., 2010) find that trustworthiness behavior is dependent on selfconcept and personality traits. Members of a social media group believe that they can predict the behavior of their peers (McKnight et al., 2002). Online and social media research (Schurr \& Ozanne, 1985; Shareef et al., 2019) agrees that predictability of peer behavior influences trustworthiness. This perception contributes to the development of favorable affective attitude (Kim, 2016).

From literature based on trust (Kumar, 1996; Moorman et al., 1992; Rousseau et al., 1998), this study defines conformity as the psychological assurance that members of a social group behave in a standard manner, reflecting unified group dynamics. Perception of conformity can also trigger predictability (Dion, 2000; Hogg, 2003; Schurr \& Ozanne, 1985). People have the freedom to act from personal desire conforming to social norms (Moorman et al., 1992; Rousseau et al., 1998). Since peers of any closed social media group have similar opinions towards social issues, there is unwritten consensus that they will behave as a group and maintain certain standards (Kumar, 1996). Social psychologists suggest that group dynamics is a complex social phenomenon, and a reflection of individual evaluations of all members (Bion, 1946; Dion, 2000). It intertwines with the coherent interactions of environmental, personal and leadership perspectives, where group members perceive conformity of standard behavior from other members (Brewer, 1991). Social identity approach supports such group dynamics and expectations of group members from each other (Brown, 2000; Gefen \& Straub, 2004).

Attribution theory (Heider, 1958) states that the underlying deficits of humans unconsciously propagate trust towards a known person, who is presumably attempting to fulfill that deficit. Social penetration (Altman \& Taylor, 1973) and system justification theories (Jost \& Banaji, 1994) also suggest that a social media group user immediately trusts peers, because they presumably have a similar personality and same level of exposure to social issues, reflecting a sense of predictability and knowledge-based familiarity. Thus, predictability leads to need-based fulfilled expectations. Perceived familiarity also helps predict peer behavior (Gefen, 2000; Hogg, 2003). Considering the fundamental essence of social identity theory (Tajfel, 1982), it can be argued that human exposure in the same continuum can gradually and silently produce feelings of familiar and similar identity, which results in unconditional trust amongst social media peers. Self-perception theory (Bem, 1967) suggests, group interactions are highly dominated, controlled, and evaluated on the assumption that they are entirely speculated and expected. 
Bandura's social learning theory (1963) affirms predictability of one's behavior due to their social surroundings and social influence. Perception of norms also supplements the behavioral strength of predictability. Familiarity with group members triggers attachments, which reflects predictability. Therefore, familiarity contributes to predictability in developing social media trust.

This study thus proposes the following hypothetical relationships,

$\mathrm{H}_{5}$ : Personality-based predictability contributes towards initial trust development

$\mathrm{H}_{5 \mathrm{a}}$ : Knowledge-based familiarity contributes towards predictability

$\mathrm{H}_{5 \mathrm{~b}}$ : Personality-based predictability contributes towards fulfilled expectations

$\mathrm{H}_{6}$ : Personality-based conformity contributes towards initial trust development

\subsection{Norms (NR) and Monitor (MN)}

Cognitive learning theory (Bandura, 1963; Mowrer, 1960) suggests, people analyze information rhetorically from the perspectives of counter logic, supporting logic, and source of derogation before believing it (Shareef et al., 2018a). Classical conditioning illustrates that a nonresponsive stimulus, if paired with a responsive stimulus can create a response. In analyzing content on social media, this cognitive component of attitude plays a crucial role in developing trustworthiness. Social media users can interpret favorable content circulated by peers and be persuaded by their mere social presence (Altman \& Taylor, 1973; Moorman et al., 1993). Information processing theory suggests that people evaluate information more cognitively and deeply, if they feel social presence of the person introducing the message (Rogers et al., 1999). In line with this argument, researchers (Ajzen, 1991; Altman \& Taylor, 1973; Gefen \& Straub, 2004; Moorman et al., 1993) reveal that norms shaping behavioral intentions and capacity to monitor are two fundamental pragmatic constructs influencing trust amongst social media peers (Aiken, 2002).

In reviewing the literature on trust (Mishra, 1995; Moorman et al., 1993), this study argues that norms can be an antecedent of initial trust development. We define norms as the effect of social surroundings on developing beliefs about social issues through social media groups. TRA provides insights on social presence focusing on norms, which suggests influence of social surroundings on development of cognitive values governing attitude (Ajzen, 1991; Dwivedi et al., 2018b; Gefen \& Straub, 2004). Media richness theory (Daft \& Lengel, 1986) suggests that perception of social presence and connectivity through social media groups can trigger persuasive feelings of trust amongst peers. Synthesizing seminal studies on trust formation (Gefen \& Straub, 2004; Mishra, 1995; Moorman et al., 1993), this study defines the concept of monitoring as the ability to connect through social presence on social media groups, which develops the perception of assurance via association and attachment. 
In analyzing the social presence theory (Altman \& Taylor, 1973; Moorman et al., 1993; Short et al., 1976), it can be inferred that due to continuous presence on social media groups, peers develop a sense of connectivity, which results in monitoring those peers who circulate information in their group (Mishra, 1995). Researchers on virtual medium assert that the key principle of virtual relationship management is to develop, maintain, and establish connectivity amongst users (McKnight et al., 2002). Applying the same principle to social media, connectivity can ensure social presence, which leads to the capacity and scope to monitor.

We thus propose the following hypotheses,

$\mathrm{H}_{7}$ : Social presence based norms contribute towards initial trust development

$\mathrm{H}_{8}$ : Social presence based monitoring contributes towards initial trust development

Based on aforementioned constructs developed by social psychologists, social science and social media researchers, this study proposes the following framework (Figure 1).

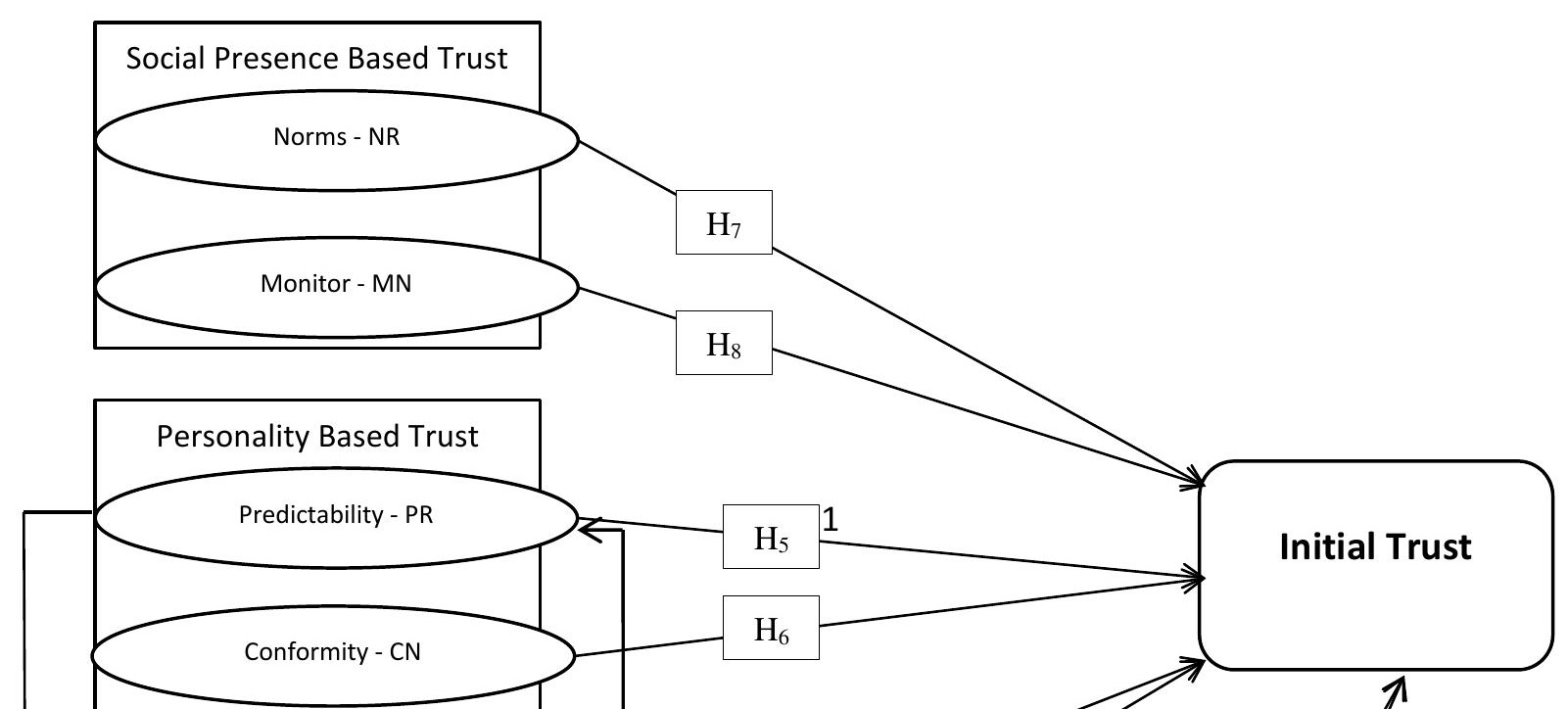


$\mathrm{H}_{5 \mathrm{~b}}$

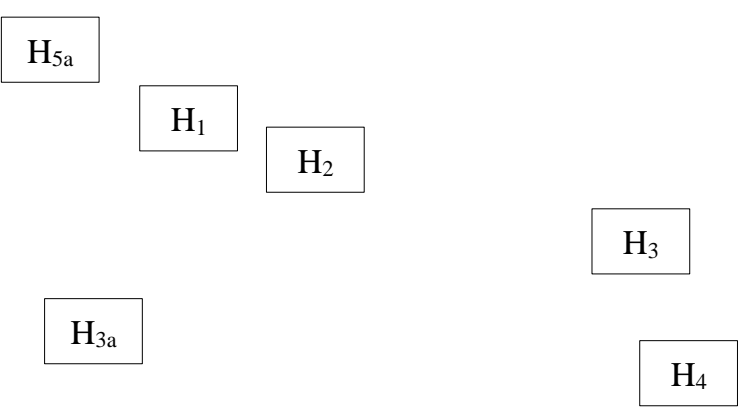

\section{Figure 1: Social Media Trust (SMT) Framework}

\section{Research Methodology}

The objective of this research is to identify the antecedents of initial trust development between peers of a social media group. We focus on the cognitive, affective, and behavioral components of attitudes that actively influence trust. The methodology followed here is consistent with other social media marketing research conceptualizing the epistemological and ontological beliefs (French, 2017; Rose \& Wood, 2005) of social media users. We employ exploratory approach to identify antecedents of initial trust formation by analyzing social psychology and trust models/theories; observing social media user behavior in trusting the content shared by their peers through a closed experiment; conducting systematic survey to capture antecedents of trustworthiness behavior; and analyzing and verifying the proposed cause-effect relationships.

Since social media is a popular and effective medium of communication in developing countries, this study focuses on members of a social media group in Bangladesh. As an emerging market, Bangladesh is an apt sample for this research. Absence of rules and regulations in market transactions is an acute problem in emerging markets like Bangladesh. Therefore, capturing perceptions of social media users in Bangladesh can provide valuable insights for the development of a grounded theory on social media trust. We target a closed Facebook group, where three research assistants (RA) appointed for this research, are active members.

\subsection{Questionnaire Development}


By reviewing the literature on trust, social media marketing, and virtual technology (Rousseau et al., 1988; Schaik et al., 2011; See-To \& Ho, 2014), 37 items for the eight aforementioned constructs - Norms (NR), Monitor (MN), Predictability (PR), Conformity (CN), Dependability (DD), Fulfilled Expectation (FE), Familiarity (FM), and Credibility (CR) and three items for the dependent construct, Initial Trust (IT) were developed. The questionnaire (Appendix A) was tested by a focus group of three university professors in Bangladesh with expertise in marketing, particularly in people behavior on social media, and two researchers with experience in launching advertisements on social media; they assessed the questionnaire for its consistency, reliability, meaning, and significance. Next, the questionnaire was tested by 25 students from a leading business school in Bangladesh, also active members of different social media groups with experience in sharing content related to social and marketing issues. We employed a 5-point Likert scale ranging from one (strongly disagree/never) to five (strongly agree/always), which is a useful instrument for measuring consumer behavior in marketing studies, and helps increase the response rate and quality (Babakus \& Mangold, 1992).

\subsection{Experimental Design}

The following message, M1 was created and circulated in a closed Facebook group with 1174 members by one of the RAs (active member of this group),

"The mobile operating company...X... claims that their call rate per minute is $0.60 \mathrm{Taka}$; however, their one minute actually measures 53 seconds. I verified it several times"

The RA circulated this message pretending that this is his independent unbiased opinion without any imposed motive. Within a week, other group members posted their own views on M1 or simply read it. Some members also shared M1 with their other groups. M1 received 717 Facebook likes. After one week of posting M1, the second RA posted the following message, M2 on the same Facebook group on her experience of using a Samsung smartphone that she recently purchased.

"The S10e is a really good phone. It has a pretty good camera and a great design"

After one week of posting M2, the third RA posted the following social message, M3 in the same group on the failure of Dhaka City Corporation to manage traffic jams.

"Road design in Dhaka city is very bad. This is the primary reason of road accidents"

All three messages (M1, M2 and M3) were created specifically for this experiment. Many members shared these messages and provided their own comments. Except the three RAs, none of the other members of the closed Facebook group were aware of the artificial design of these messages. While some members of the group posted original messages (from their personal experiences) during the experiment, we chose to post and analyze the response to these three 
artificially designed messages to understand group members' trust formation behavior towards specific opinions.

\subsection{Data Collection}

After a week, one of the RAs introduced an author of this paper to the members of this closed Facebook group as the researcher. The questionnaire with 37 items was emailed to all 1174 members of the group, requesting a response. The members were asked - if they read and share the content posted by their peers in their Facebook group, if they positively perceive such content sharing, and if they trust the knowledge, experience, and evaluation of their group peers.

Our sample size is representative of the Bangladeshi population interacting on social media (Shareef et al., 2018a). Altogether, 282 responses were received. While some members of this Facebook group are friends and known to one another in personal life (outside Facebook), most members are colleagues. They belong to different social groups - students, working people, social activists, and self-employed people. The average age of our respondents is 29.5 years, of which 57 percent respondents are male and 43 percent are female. About 37 percent respondents are working class people (employees in different organizations), 33 percent are students, and the rest belong to different groups. Education wise, most respondents have a university degree.

\section{Research Results}

Sample adequacy was examined using the Kaiser-Meyer-Olkin (KMO) test as a basis of fitness. Kaiser (1974) proposed that a KMO < 0.5 suggests factor analysis is inappropriate. For this study, the KMO value was 0.846, indicating sample adequacy. The Bartlett Sphericity test was also significant at 0.000. We employed structural equation modeling (SEM), a multivariate technique to reveal relationships between the constructs and their scale items via a reflective model, and cause-effect relationships between the dependent and independent constructs via a formative model. SEM verifies the reflective and formative relationships via the measurement and structural models. Measurement model examines the reflective relationships between the latent variables and their respective observed items through confirmatory factor analysis (CFA). Structural model represents the relationships between the latent variables and the dependent construct, i.e., the cause-effect relationships. A two-step approach, where the confirmatory measurement model precedes the structural model was undertaken (Anderson and Gerbing, 1988).

\subsection{Validity Testing}

This study undertook CFA to examine and verify the validity and acceptance of the scale items for all shortlisted constructs. All eight independent variables and one dependent variable showed an over-identified model. The CFA analysis and loading patterns confirmed that the reflective 
indicators appropriately measured their respective unobserved variables. The CFA results confirmed construct validity (Chau, 1997). The measuring items loaded onto their respective constructs at values over 0.50, except the following six items - DD4, FM4, CR1, CR5, NR4, and MN4. At this point, the cut off value was set with the assumption that any scale item loading at < 0.50 does not make significant contributions towards the formation of the construct, and can thus be removed (Kline, 2011). After the removal of these six scale items, all measuring items loaded at values exceeding 0.50, confirming convergent validity (Fornell \& Larcker, 1981; Kline, 2011).

It is also important to confirm the discriminant validity for the cause-effect relationships in the formative model. Measurement model showed the largest shared variance between the independent factors was lower than the least average variances extracted (AVE) for each factor and its measures (Chau, 1997). The variance-extracted test was undertaken to verify discriminant validity, which is ensured between two constructs if both their variances are greater than the squared correlations between the two constructs (Fornell \& Larcker, 1981). Results in table 1 show the lowest AVE value is 0.928 (for PR), which is higher than the largest squared correlation between any pair of constructs ( 0.47 - between DD and CR). Therefore, discriminant validity is confirmed for this dataset. Finally, eight independent constructs with 31 measuring items and one dependent variable with three measuring items were shortlisted.

Table 1: Correlation Matrix and AVE of Independent Constructs

\begin{tabular}{|l|l|l|l|l|l|l|l|l|}
\hline Constructs & DD & FE & FM & CR & PR & CN & NR & MN \\
\hline Dependability (DD) & $\mathbf{0 . 9 6 7}$ & & & & & & & \\
\hline Fulfilled Expectations (FE) & 0.049 & $\mathbf{0 . 9 6 3}$ & & & & & & \\
\hline Familiarity (FM) & 0.029 & 0.396 & $\mathbf{0 . 9 6 5}$ & & & & & \\
\hline Credibility (CR) & 0.470 & 0.025 & 0.018 & $\mathbf{0 . 9 6 4}$ & & & & \\
\hline Predictability (PR) & 0.047 & 0.381 & 0.396 & 0.041 & $\mathbf{0 . 9 2 8}$ & & & \\
\hline Conformity (CN) & 0.044 & 0.012 & 0.026 & 0.061 & 0.004 & $\mathbf{0 . 9 7 2}$ & & \\
\hline Norms (NR) & 0.012 & 0.160 & 0.277 & 0.052 & 0.277 & 0.011 & $\mathbf{0 . 9 4 6}$ & \\
\hline Monitor (MN) & 0.005 & 0.149 & 0.243 & 0.013 & 0.135 & 0.0004 & 0.267 & $\mathbf{0 . 9 6 0}$ \\
\hline
\end{tabular}

Diagonals are square root of AVE and others are squared correlations

\subsection{Reliability Testing}

Composite reliability scores indicate internal consistency of the scale items to measure any latent construct, and are estimated by the standardized factor loadings and indicator's measurement error (Fornell \& Larcker, 1981). For internal consistency, a composite reliability score $>0.7$ is acceptable (Fornell and Larcker, 1981; Hair et al., 2006). This study found the composite reliability scores of all latent variables to be higher than 0.7 , indicating adequate consistency amongst the scale items to measure their corresponding latent variables (Table 2).

Table 2: Composite Reliability and Mean Score 


\begin{tabular}{|c|c|c|}
\hline Constructs & Composite Reliability & Mean Score \\
\hline Dependability (DD) & 0.947 & 2.61 \\
\hline Fulfilled Expectations (FE) & 0.945 & 4.01 \\
\hline Familiarity (FM) & 0.946 & 4.02 \\
\hline Credibility (CR) & 0.946 & 2.72 \\
\hline Predictability (PR) & 0.901 & 4.05 \\
\hline Conformity (CN) & 0.954 & 3.02 \\
\hline Norms (NR) & 0.922 & 4.02 \\
\hline Monitor (MN) & 0.934 & 4.09 \\
\hline
\end{tabular}

\subsection{Cause-Effect Relationships for Social Media Trust}

SEM (LISREL) was employed for the structural part of the model to examine the hypothesized cause-effect relationships. Correlation matrix of independent and dependent variables was used as the data input for a maximum likelihood procedure. Primary analysis indicated the model did not fit well with the sample data. Both unstandardized and standardized regression weights (factor loadings) for the cause-effect relationships were verified. We found - dependability, credibility, and conformity did not predict initial trust formation, as their path coefficients were not significant $(<0.05)$. Therefore, these constructs do not contribute towards initial trust development amongst social media peers. However, all other causal relationships and independent variables - fulfilled expectation, predictability, familiarity, monitor, and norms were found significant at 0.05 .

The fit indices, Chi-Square $=40.31, \mathrm{df}=10, \mathrm{P}$-value $=0.000001$, and root mean square error of approximation $($ RMSEA $)=0.104$ were not acceptable, and did not fit well with the model. The fitness indices suggest a causal relationship from norms to predictability. Before accepting this recommendation for model improvement, the correlation coefficient between these two constructs was examined. Theoretical justification for the probable inclusion of this relationship in the original theoretical framework was also verified (explained in section 6) before introducing this relationship and reanalyzing the model. This time, the primary fit indices showed that the model cannot be rejected (Chi-Square $=14.61$, df $=9$, P-value $=0.10234$, RMSEA = 0.047). This result indicates that the null hypothesis of the model is a good fit for the data. Therefore, the outcome suggests that the initial social media trust formation is substantially influenced by - fulfilled expectation, predictability, familiarity, monitor, and norms (Figure 2).

The relationships of all independent variables with initial trust formation and their values are shown in the following equation: $\mathrm{IT}=0.400 * \mathrm{FE}+0.279 * \mathrm{PR}+0.0330 * \mathrm{DD}+0.216 * \mathrm{FM}-$ $0.00405 * \mathrm{CR}+0.0616 * \mathrm{CN}+0.0948 * \mathrm{NR}+0.136 * \mathrm{MN}$

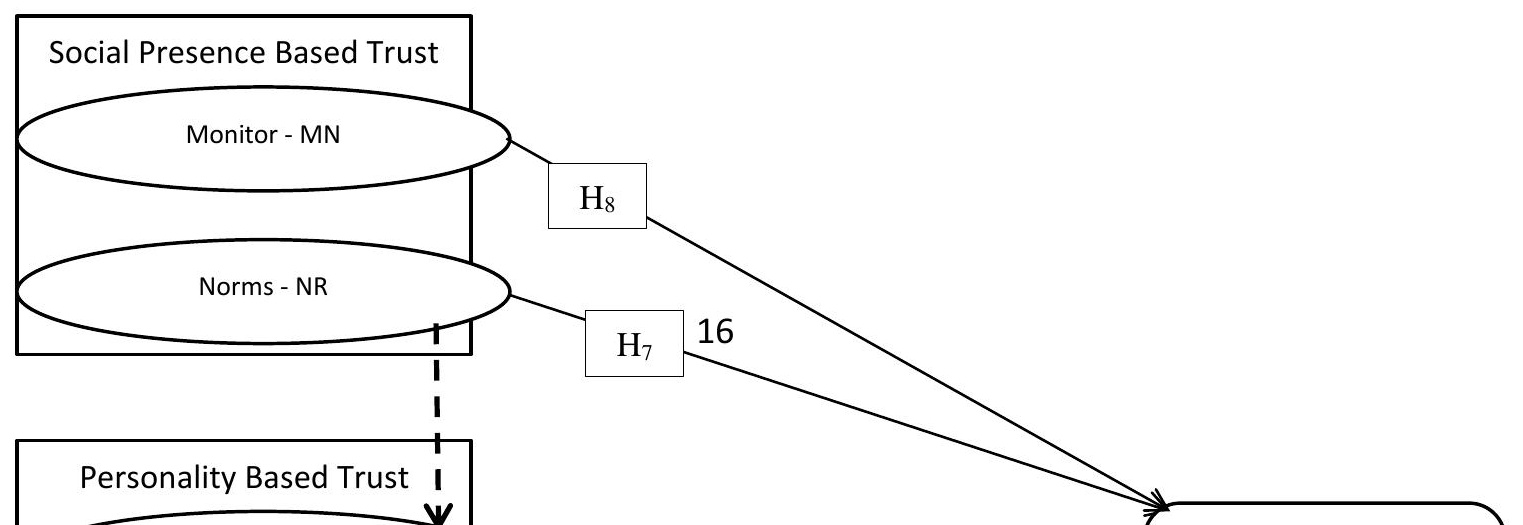


$\mathrm{H}_{5}$

$\mathrm{H}_{5 \mathrm{~b}}$

$\mathrm{H}_{2}$

$\mathrm{H}_{3}$

$\mathrm{H}_{3 \mathrm{a}}$

*Dashed line represents the new hypothesized relationship

Figure 2: Final SMT Model

Other fit indices, such as comparative fit index (CFI), goodness of fit index (GFI), adjusted goodness of fit index (AGFI), normed fit index (NFI), root mean square error of approximation (RMSEA), and relative fit index (RFI) were compared with recommended values (Iacobucci, 2010; Kline, 2011), and found acceptable (Table 3).

Table 3: Fit Indices for SMT Model

\begin{tabular}{|c|c|c|}
\hline Fit Measures & SMT Model & Recommended Values \\
\hline Chi-square $(\chi 2)$ & $14.61(0.10234)$ & $\mathrm{p} \geq 0.05$ \\
\hline Degrees of Freedom & 9 & $\leq 3.0$ \\
\hline$\chi 2$ Degree of freedom (DF) & 1.623 & $\geq .90$ \\
\hline CFI & 0.996 & $\geq .90$ \\
\hline GFI & 0.989 & $<0.06$ \\
\hline RMSEA & 0.047 & $\geq 0.90$ \\
\hline NFI & 0.989 & $\geq 0.90$ \\
\hline AGFI & 0.944 & \\
\hline
\end{tabular}




\section{Discussions}

Fulfilled Expectations have the highest influence on SMT formation. It has a loading value of 0.40 , suggesting a unit positive change in FE results in a positive change on SMT by a value of 0.40 , if other significant contributing factors - PR, FM, MN, and NR are kept constant. The second highest contributor is predictability at 0.28 . The contributions of other variables are $F M=$ $0.22, \mathrm{MN}=0.14$, and $\mathrm{NR}=0.10$. The squared multiple correlation coefficient, $\mathrm{R}^{2}=0.854$ indicates the amount of variance the independent constructs - FE, PR, FM, MN, and NR can explain. This means $85.4 \%$ of the variance in initial formation of trust is explained by these five significant independent variables. In a social science study, where respondents are the true population, this amount of variance explained by independent variables is quite satisfactory (Kline, 2011).

Fulfilled expectation, predictability, familiarity, monitor, and norms significantly contribute towards initial trust amongst social media peers $(\mathrm{H} 2, \mathrm{H} 3, \mathrm{H} 5, \mathrm{H} 7, \mathrm{H} 8$ : accepted). At the same time, this study confirms the non-significant influence of dependability, credibility, and conformity towards initial trust (H1, H4, H6: rejected). This study also confirms that knowledgebased familiarity significantly contributes to the development of need-based fulfilled expectations and personality-based predictability (H3a, H5a: accepted). Predictability also significantly contributes towards fulfilled expectations (H5b: accepted). For better model fit, a new cause-effect relationship from social presence based norms to personality-based predictability was introduced.

Content theory of motivation (Alderfer, 1969; Maslow, 1943) suggests - the need to fulfill a deficiency can unconsciously intensify personal support towards something that has the plausibility to supplement that deficiency. These endeavors in the form of unconscious support ultimately transform into initial trust. This type of emotional investment is dictated by the eagerness to trust peers on social media with intentions of eliminating deficiencies. Due to absence of freedom of speech, equal rights, censored media, poverty, exercise of power by political and upper class people, social discrepancy, and other irregularities, majority people in developing countries feel suppressed, and unable to fulfill their social desires. When they find someone in their social media group making a case against such discrepancies whilst upholding social commitment, they immediately feel a strong urge to support that person without verifying authenticity (McCarthy, 2009). This urge to fulfill or supplement a social deficiency directs them so profoundly that they instantaneously trust the content initiator and the content.

Common psychology is for people to associate and compare themselves with a socially known person. Social comparison theory (Festinger, 1954) proposes that in evaluating social issues, group members compare themselves with socially relevant people. Exposure to members who initiate and share views on a social media group creates psychological attachment, which triggers 
perceptions of familiarity. Familiarity developed from group interactions has collectivist influence on social issues, as suggested in social identity theory (Tajfel, 1982). Considering social penetration theory (Altman \& Taylor, 1973) and Bandura's (1963) social learning theory, group dynamics depend on the relationships between social members correlated with familiarity. Such knowledge and scope of evaluating peer performance triggers peer trust (Pennington, 2008). Therefore, familiarity about peer intentions and motives supplements trust formation.

Continuous communication with peers acting as a family on a social media group leads to the development of affective and cognitive attitude of social presence that can be associated with social penetration theory (Altman \& Taylor, 1973). This intertwined presence pursues feelings of capacity, scope, and ability to monitor group members with similar mentality and standard (norms). As findings suggest, monitor and norms are directly associated with social media trust. Influence of surroundings reflects in norms and increases predictability. TPB (Ajzen, 1991) asserts group behavior is dominated by socially surrounded people i.e. subjective norms, as they are continuously connected on social media. Social comparison theory (Festinger, 1954) acknowledges that people bear feelings that connects them to a group with the same mentality and psychological behavior. Norms is an influential perception about peers, given their constant presence and repeated exchange of ideas on social media (McCarthy, 2009). Social presence on the same social media group results in connectivity, which is traceable (French, 2017). Such traceable attachment supplements the feeling of assurance amongst peers. With time, people become habituated to depend on their peers for forming consensual group opinions (Frey \& Jegen, 2001). Being unconsciously influenced by the group in the preliminary stages, social media peers gradually discover that interdependency has control on their group behavior and their own attitude (McCarthy, 2009). Therefore, norms and monitor contribute to the development of initial social media trust.

While five variables - fulfilled expectation, predictability, familiarity, monitor, and norms emerged significant, three variables - dependability, credibility, and conformity (H1, H4 and H6) were non-significant. In investigating the insignificant contributions, we found that these three variables indicate relationships with SMT at an individual level. Since social media interactions characterize group behavior, trust amongst group members renders the group as a unified entity (Griffin et al., 2015; Kim, 2016). Trust in sharing opinions reflects group behavior and thus, effects of personal deficiency (DD), evaluation of personal authenticity (CR), and assurance of personal standard $(\mathrm{CN})$ are not coherently associated with social group dynamics. Interaction on social media is not an idiosyncratic or individualistic phenomenon; rather, it reflects the desire for collective behavior, which gradually unites group peers in representing a social identity (Tracy \& Tretheway, 2005). Such behavioral transformation stems from social identity theory as social categorization (Floyd, 2011; Tajfel, 1982), justifying the non-significant influence of dependability, credibility, and conformity towards initial social media trust development.

Social media group members do not evaluate the content posted by peers based on their discrete relationship with the sender (Kim, 2016). From the findings of this study, it is obvious that any 
member of a social media group evaluates his/her association with other members in the light of group coherence. Consequently, there is no scope of personal dependency on any individual peer, and thus, dependability is not a significant construct in this context. Similarly, individual credibility or sender's authenticity is not an issue for the group members to dispose trustworthiness in social media interactions (Griffin et al., 2015). Members of social media groups contain strong and eternal beliefs that whatever they share amongst peers represents their group characteristics. Therefore, social media activists do not evaluate individual assurance, reflecting personal conformity in developing initial trust, i.e. conformity does not contribute towards the SMT model (Kim, 2016).

The findings of this study have potential implications and contributions, both theoretically and practically. The model suggests that group learning is more effective in developing trust (supported by Shin \& Park, 2019). The process of developing trust on social media, as conceptualized in the SMT model, can guide social media researchers on trust and associated peer behavior. It also offers insights to marketing managers on consumer behavior to understand, reshape, and regulate favorable consumer attitude towards their products/services via social media interactions.

It is a burning issue, particularly for the emerging markets. Social scientists affirm that developing economies like China, India, Brazil, South Africa, Bangladesh, Vietnam, Indonesia etc. are emerging markets in the true sense of development (Eltantawy \& Wiest, 2011; Lee \& Chan, 2015). In terms of economy, these countries are expanding with a prolific share of new consumers; however, many social scientists are skeptical about their development in the context of good governance (Eltantawy \& Wiest, 2011). It is widely believed that freedom of speech and right to express personal/social opinions are suppressed in developing countries (Ems, 2014; Lee \& Chan, 2015). As a result, people in such countries resort to social media to share opinions (Eltantawy \& Wiest, 2011; Haciyakupoglu \& Zhang, 2015). While social media provides a platform to develop persuasive opinions, it can become detrimental when used to introduce biased opinions that can influence group behaviors to have a negative impact on the economy/society/nation (Haciyakupoglu \& Zhang, 2015). Thus, for emerging markets, analyzing group behavior in the context of social media interactions is an issue of utmost importance.

\subsection{Theoretical Contributions}

From our findings and the epistemological and ontological paradigms of the shortlisted constructs, we conclude that SMT is governed by the affective component of attitude. Fulfilled expectations, predictability, and familiarity are shaped from the affective components of trust,

and reflect a sense of belonging and emotional investment via social connectivity. Capacity and scope to monitor and social influence for norms are largely dependent on cognitive feelings; 
however, their contribution is not significant in comparison to the three affective components of attitudinal beliefs (FE, PR and FM). This study finds that human behavior in trusting peers on social media is not developed from any logical interference; rather, it is governed by affective attitude towards social media peers. It also suggests that by interacting on social media groups, peers gradually develop coherent social bonds with those having similar ideals in life.

Social media drives individual behavior, and people on this platform connect with peers and regard such connectedness as a form of personalization (Wang et al., 2012). This connectivity behavior and gradual closeness via social presence leads to in-group bonding (Aiken, 2002). This slowly injects an urge to be associated with peers of unified opinions (Aday et al., 2013). Observational learning theory (Riopelle, 1960) clarifies the concept of group formation (Zentall, 2012). Close observation of group members' behavior (exposure to their personality and knowledge) on social media results in peers developing affective beliefs in trusting each other's opinion without scrutiny (Hughes, 2011). According to this finding, any social deficiency and acknowledgement of similar mindset on social media groups leads to systematic development of trust, reflecting the essence of observational learning through social presence.

Social cognitive learning theory (Bandura, 1963) suggests such trust formation behavior is unconditional and develops unintentionally by sharing emotions on social media platforms like Facebook. Willing and spontaneous sharing of psychological feelings is fundamentally an emotional exchange, often preoccupied with a belief of social presence (Bandura, 1989; Eltantawy \& Wiest, 2011; Ems, 2014). People learn from each other while acting as close associates, presumably without personal interest or commercial motives (Shin \& Park, 2019). Over time, psychological feelings grow and develop long-term relationships (Haciyakupoglu \& Zhang, 2015; Lee \& Chan, 2015). Within a group, they show their commitment for each other, which is an essential prerequisite of trustworthiness. Therefore, verification of authenticity of any content shared in that group is not questioned by the peers, rather they trust any and all shared opinions circulating in their group. Such group behavior is explained by social identity and social penetration theories, which postulate - psychological urge to form a group is essentially reflecting social collectivism, which is easily achieved by connectivity on social media (Akar \& Topcu, 2011). This group coherence indicates the process of emotional investment, which is predominantly unconditional (Butler, 1991; Ganesan, 1994). This group behavior is supported by recent scholarly research focused on cognitive social learning (Ems, 2014; McAlister et al., 2008; Pajares et al., 2009; Shin \& Park, 2019).

Literature on trust behavior and social media interactions particularly focuses on integrity, benevolence, and caring attitude (Butler, 1991; Ganesan, 1994). Several articles show emotional urge and dependability as fundamental reasons for unconditional trust formation (Blau, 1964; Giffin, 1967). Social psychologists propose - social expectations develop and diffuse from social deficiencies and propagate through shared values (Griffin et al., 2015). Several researchers suggest that trust is formed without verified knowledge of biasness, and is spread due to feelings of mutual integrity and caring attitude (Gefen \& Silver, 1999). In addition, social groups can 
generate a sense of connectedness, traceable by group members. This belief is particularly relevant for social media platforms, as they are connected round the clock. Thus, this SMT framework further strengthens trust literature, and introduces a new avenue, which can help in the development of SMT theory.

\subsection{Implications for Practice and Policy}

Social media is evolving as a potential marketing channel for companies to reach customers, promote products, change beliefs and attitudes, and establish market standards via group dynamics (Haciyakupoglu \& Zhang, 2015; Lee \& Chan, 2015). Insights into users' group behavior and categorization of group dynamics can significantly improve the understanding of consumer characteristics. Therefore, in heuristically evaluating SMT formation patterns, the findings of this study have potential implications for managers. Corporate marketing managers struggling to promote their products are now looking to utilize social media platforms. Consumers of emerging markets are increasingly influenced by product information and user experience shared by members of social media groups (Shareef et al., 2018a). The SMT framework can offer valuable insights for marketing managers to design their promotional strategy on social media.

This study investigates the antecedents of trust formation behavior on social media, and finds affective component of attitude has substantial impact on trust between peers. By exploring this behavior, marketing managers can develop their strategic paradigm to gain consumer trust towards their products. Instead of product promotions focused on models and celebrities, managers can focus on consumers with some sort of social media presence and prior experience of using their products. They can design marketing strategies to reach a larger consumer mass with minimum efforts on social media, whereby these consumers share opinions of using their products to develop positive consumer attitudes and beliefs towards those products.

This study identifies another interesting avenue of investigating biased peers with intentions to promote pre-determined agendas amongst members of a group. Policymakers can shed light on how rumors diffuse in social media groups, and focus on the ills of non-verification group behavior. The SMT model can increase policymakers' understanding of social group behavior, trust patterns and its antecedents. It is clear from our findings that in promoting peer opinions, limited cognitive judgement is applied. Therefore, social psychologists should be mindful that group members can trust without speculations or critical thinking. SMT behavior is increasingly influenced by attitude towards peers in the group, where there is mutual trust without reservations.

\section{Conclusions}

This empirical study explores the trust development process on social media platforms. We develop a theoretical framework for the antecedents of social media trust, which influence the willingness of social media users to believe in the product/service/social content shared by their 
peers. The study's findings have significant implications for policymakers, social psychologists, and marketing people, as they offer valuable insights on people behavior. We undertake this study in Bangladesh, since developing countries are more prone to social, political, and economic instability, following rumors on social media networks. We analyze and account for the views of several social, psychological, and marketing theories to understand human behavior. This involves review of existing literature on trust and variables influencing trustworthiness. By accounting for the affective, cognitive, and behavioral components of belief and attitude, we propose the SMT model to measure eight predictors of trust - Norms, Monitor, Predictability, Conformity, Dependability, Fulfilled Expectation, Familiarity, and Credibility.

A well-structured closed experiment was conducted with three RAs, who circulated opinions related to recent social, marketing, and economic issues gathered from personal experience. Members of the targeted social media group were observed, and 282 responses were analyzed. SEM was employed to verify the proposed hypotheses. Findings revealed that social deficiency based fulfilled expectation is the most significant contributor of initial trust development amongst peers of a social media group. In terms of relative importance, personality-based predictability, knowledge-based familiarity, and social presence based monitor and norms significantly contribute to the development of unconditional trust. Familiarity and predictability significantly influence the perception of social deficiency based fulfilled expectations. In addition, familiarity has a significant effect on predictability. A new relationship, justified from the social theory lens, emerged with norms having a significant impact on predictability. However, the analysis revealed non-significant effects of conformity, dependability, and credibility on initial trust. Therefore, five predictors of social media trust were confirmed - fulfilled expectations, predictability, familiarity, monitor, and norms. Thus, this study presents a grounded theory on social media trust as a framework for conceptualizing trust patterns of peers interacting on social media platforms.

\subsection{Limitations and Future Research}

Like any social science research, this study has several limitations. In designing the experiment, three RAs posted timed messages related to three subjects (economic, social, and marketing) within the group. Such artificial setting is a limitation, and future researchers must investigate real-time interactions of social media users. In addition, people may have different responses for different subjects; thus, future researchers may explore marketing and social issues separately. Many researchers believe that consumers of developed countries can have different attitudes and responses towards the same subject (Cadogan, 2010; Espinoza, 1999; Posey et al., 2010). Thus, the SMT model proposed in this study should be applied in a developed country to capture the different cultural orientations. For generalization purposes, this framework can be replicated in similar cultural settings to confirm the findings. In addition, this research did not consider the effects of any control variables, i.e. the demographic characteristics. Age, gender, income, and education may have significant effects as the moderating variables on the SMT framework, which should also be investigated in the future. Demographic characteristics of all the 
respondents were collected; however it was not possible to reveal the same for any unknown members of that group.

\section{Reference}

Aiken, L. R. 2002. Attitudes and related psychosocial constructs: Theories, assessment, and research. Thousand Oaks, CA: Sage Publications.

Ajzen, I., (1991), The Theory of Planned Behavior, Organizational Behavior and Human Decision Processes, 50(2), 179-221.

Aday, S., Farrell, H., Freedon, D., Lynch M., Sides J., \& Dewar M. (2013). Watching from afar: Media consumption patterns around the Arab spring. American Behavioral Scientist, 57(7), 899-919.

Akar, E., \& Topcu, B. (2011). “An examination of the factors influencing consumer's attitudes toward social media marketing”. Journal of Internet Commerce, 1(10), 35-67.

Alalwan, A. A., Rana, N. P., Dwivedi, Y. K., \& Algharabat, R. (2017). Social media in marketing: A review and analysis of the existing literature. Telematics and Informatics, 34(7), 1177-1190.

Aladwani, A. M., \& Dwivedi, Y. K. (2018). Towards a theory of SocioCitizenry: Quality anticipation, trust configuration, and approved adaptation of governmental social media. International Journal of Information Management, 43, 261-272.

Allison, P. D., (1999), Logistic Regression Using the SAS System, Cary, NC: SAS Institute.

Alderfer, Clayton P. (1969). "An empirical test of a new theory of human needs". Organizational Behavior and Human Performance, 4 (2): 142-75.

Anderson, J. C. and D. W. Garbing, (1988). Structural equation modeling in practice: a review and recommended two-step approach. Psychological Bulletin, 103(3), 411-423.

Anduiza, E., Cristancho, C., \& Sabucedo, J. M. (2014). Mobilization through online social networks: The political protest of the indignados in Spain. Information, Communication \& Society, 17(6), 750-764.

Altman I, \& Taylor D. (1973). Social penetration: The development of interpersonal relationships. New York: Holt.

Anderson, C.A.; Bushman, B.J. (2001). Effects of violent video games on aggressive behavior, aggressive cognition, aggressive affect, physiological arousal, and pro-social behavior: A meta-analytic review of the scientific literature. Psychological Science. 12(5): 353-359.

Angeli, C., Valanides, N., Polemitou, E., \& Fraggoulidou, E. (2016), An interaction effect between young children's field dependence-independence and order of learning with glass- 
box and black-box simulations: Evidence for the malleability of cognitive style in computersupported learning, Computers in Human Behavior, vol. 61, 569-583.

Astington, J. W. (2003). Sometimes necessary, never sufficient: False-belief understanding and social competence. In B. Repacholi \& V. Slaughter (Eds.), Individual differences in theory of mind: Implications for typical and atypical development (pp. 13-38). New York, NY, US: Psychology Press.

Babakus, E. \& Mangold, W. G. (1992).Adapting the SERVQUAL scale to hospital services: an empirical investigation. Health Services Research, 26(6), 767-86.

Bagozzi, R. P., Bergami, M., Marzocchi, G. L., \& Morandin, G. (2012). Customer-organization relationships: Development and test of a theory of extended identities. Journal of Applied Psychology, 97, 163-176.

Bandura, A. (2002, March). Growing primacy of human agency in adaptation and change in the electronic era,. European Psychologist, 7(1), 2-16.

Bandura, A. (1989). "Human Agency in Social Cognitive Theory" (PDF). American Psychologist. 44 (9): 1175-1184.

Bandura, Albert (1963). Social learning and personality development. New York: Holt, Rinehart, and Winston.

Barnes, N.G. and Mattson, E. (2009), "Social media in the 2009 Inc. 500: new tools and new trends", Journal of New Communication Research, 4(2), 70-9.

Bem, D. J. (1967). Self-Perception: An Alternative Interpretation of Cognitive Dissonance Phenomena. Psychological Review, 74, 183-200.

Bion, W. R.(1946). Leaderless group project, Bulletin of the Menninger Clinic, 10: 77-81.

Blau PM. Exchange and power in social life. New York: Wiley; 1964.

Brewer, M. B. (1991). "The Social Self: On Being the Same and Different at the Same Time". Personality and Social Psychology Bulletin, 17 (5): 475-482.

Brown, Rupert (1 November 2000). "Social Identity Theory: past achievements, current problems and future challenges". European Journal of Social Psychology, 30 (6): 745-778.

Butler JKJ. Toward understanding and measuring conditions of trust: evolution of a conditions of trust inventory. Journal of Management, 1991;17(3):643-63.

Cadogan, J. (2010), Comparative, cross-cultural, and cross-national research: a comment on good and bad practice, International Marketing Review, 27(6), 601-605.

Cao, X., \& Yu, L. (2019). Exploring the influence of excessive social media use at work: A three-dimension usage perspective. International Journal of Information Management, 46, 83-92. 
Chau, P.Y.K. (1997). Reexamining a model for evaluating information center success: using a structural equation modeling approach. Decision Sciences, 28(2), 309-334.

Chu, S-C., (2011). Viral advertising in social media: Participation in Facebook groups and responses among college-aged users. Journal of Interactive Advertising, 12(1), 30-43.

Daft, R.L.; Lengel, R.H. (1986). "Organizational information requirements, media richness and structural design". Management Science, 32 (5): 554-571.

Damodaran L, Nicholls J, Henney A. The Contribution of Sociotechnical Systems Thinking to the Effective Adoption of e-Government and the Enhancement of Democracy. The Electronic Journal of e-Government, 2005;3(1):1-12.

Dion, K. L. (2000). "Group cohesion: From "field of forces" to multidimensional construct". Group Dynamics: Theory, Research, and Practice, 4: 7-26.

Dwivedi, Y. K., Rana, N. P., Slade, E. L., Shareef, M. A., Clement, M., Simintiras, A., \& Lal, B., (2018a), Emerging Markets from a Multidisciplinary Perspective, Challenges, Opportunities and Research Agenda, Springer, USA.

Dwivedi, Y. K., Shareef, M. A., Mukerji, B., Rana, N. P., \& Kapoor, K. K. (2018b). Involvement in emergency supply chain for disaster management: a cognitive dissonance perspective. International Journal of Production Research, 56(21), 6758-6773.

Dwivedi, Y. K., Shareef, M. A., Simintiras, A. C., Lal, B., \&Weerakkody, V. (2016), Adoption Behaviour for Mobile Health (m-Health) Service: A Cross-Country Comparison. Government Information Quarterly, 33(1), 174-187.

Dwivedi, Y. K., Kapoor, K. K., \& Chen, H. (2015). Social media marketing and advertising. The Marketing Review, 15(3), 289-309.

Eltantawy, N., \& Wiest, J. B. (2011). Social media in the Egyptian revolution, reconsidering resource mobilization theory. International Journal of Communication, 5, 1207-1224.

Ems, L. (2014). Twitter's place in the tussle: How old power struggles play out on a new stage. Media, Culture \& Society, 36(5), 720-731.

Espinoza, M. M., (1999), Assessing the cross-cultural applicability of a service quality measure A comparative study between Quebec and Peru, International Journal of Service Industry Management, 10(5), 449-468.

Festinger L (1954). "A theory of social comparison processes". Human Relations. 7 (2): $117-$ 140.

Fishbein, M. \& Ajzen, I. (1975), Beliefs, Attitude, Intention, and Behavior: An Introduction to Theory and Research, Reading, MA: Addison-Wesley.

Fishbein, Martin (1963), An Investigation of the Relation- ships Between Beliefs About an Object and the Attitude Toward the Object, Human Relations, 16, 233-40 
Floyd, K. (2011). Interpersonal Communication (2nd ed.). New York, NY: McGraw-Hill Education.

Frey, B.S. and Jegen, R. (2001). Motivation Crowding Theory. Journal of Economic Surveys 15(5), 589-611.

Fiske AP. (2000). Complementarity theory: why human social capacity evolved to require cultural complements. Personality and Social Psychology Review, 4, 76-94.

Fornell, C., \& Larcker, D. F. (1981). Evaluating structural equation models with unobservable variables and measurement error. Journal of Marketing Research, 18(1), 39-50.

French, A. M. (2017), Let's meet offline: A mixed-methods approach exploring new trends in social networking, Information Technology \& People, 30(4), 946-968.

Fukuyama F. (1995). Trust: the social virtues and the creation of prosperity. New York, NY: The Free Press.

Ganesan S. (1994). Determinants of long-term orientation in buyer-seller relationships. Journal of Marketing, 58(2), 1-19.

Gefen, D., and Straub, D. (2004). Consumer Trust in B2C e-Commerce and the Importance of Social Presence: Experiments in e-Products and e-Services, Omega, 32(6), 407-424.

Gefen D, Karahanna E, Straub DW (2003). Trust and TAM in online shopping: an integrated model. MIS Quarterly, 27(1), 51-90.

Gefen D. (2002). Reflections on the Dimensions of Trust and Trustworthiness Among Online Customers. ACM SIGMS Database, 33(3), 38-53.

Gefen D. (2000). E-commerce: the role of familiarity and trust. Omega, 28(6), 725-37.

Gefen D, Silver M. (1999). Lessons learned from the successful adoption of an ERP system. In: Proceedings of Fifth International Conference of the Decision Sciences Institute (DSI), Athens, Greece, 1999, Published, 1054-7.

Giffin, K. (1967). The contribution of studies of source credibility to a theory of interpersonal trust in the communication process. Psychological Bulletin, 68(2), 104-20.

Griffin, E. A., Ledbetter, A., \& Sparks, G. G. (2015). A First Look at Communication Theory (9th ed.). New York: McGraw-Hill Education.

Goles T, Rao S, Lee S, \& Warren J. (2009). Trust Violation in Electronic Commerce: Customer Concerns and Reactions. Journal of Computer Information Systems, 49(4), 1-9.

Habibi, M. R., Laroche, M., \& Richard, M.-O. (2014). Brand communities based in social media: How unique are they? Evidence from two exemplary brand communities. International Journal of Information Management, 34(2), 123-132. 
Haciyakupoglu, G., \& Zhang, W. Y. (2015). Social media and trust during the Gezi protests in Turkey. Journal of Computer-Mediated Communication, 20(4), 450-466.

Hart P, Saunders C. Power and trust: critical factors in the adoption and use of electronic data interchange. Organizational Science, 8(1), 23-42.

Heider. F (1958). The psychology of interpersonal relations. New York: Wiley.

Ho, J. Y.C., \& Dempsey, M. (2010). Viral Marketing: Motivations to Forward Online Content, Journal of Business Research, 63(9-10), 1000-06.

Hogg, M. A. (2003). Social identity. In M. R. Leary \& J. P. Tangney (Eds.), Handbook of self and identity (pp. 462-479). New York, NY: Guilford Press.

Homans, George (1961). Social Behavior: Its Elementary Forms. New York: Harcourt Brace Jovanovich.

Hosmer LT. (1995). Trust: the connecting link between organizational theory and philosophical ethics. Academy of Management Review, 20(2), 379-403.

Hughes, Claire (2011). Social Understanding and Social Lives. New York, Ny: Psychology Press.

Jarvenpaa S, Tractinsky N, Vitale M. (2000). Consumer Trust in an Internet Store, Information Technology and Management, 1(1-2), 45-71.

Jarvenpaa SL, Tractinsky N. (1999). Consumer trust in an internet store: a cross-cultural validation. Journal of Computer Mediated Communication, 5(2), 1-35.

Jost, John T.; Banaji, Mahzarin R. (1994). The role of stereotyping in system-justification and the production of false consciousness. British Journal of Social Psychology, 33, 1-27.

Kapoor, K. K., Tamilmani, K., Rana, N. P., Patil, P., Dwivedi, Y. K., \& Nerur, S. (2018). Advances in social media research: past, present and future. Information Systems Frontiers, 20(3), 531-558.

Kim, Jihyun (2016). Celebrity's Self-disclosure on Twitter and Parasocial Relationships: a Mediating Role of Social Presence. Computers in Human Behavior, 62, 570-577.

Kim A. J, Ko, E. (2012). Do social media marketing activities enhance customer equity? An empirical study of luxury fashion brand. Journal of Business Research, 65(10), 1480-86.

Kizgin, H., Dey, B. L., Dwivedi, Y. K., Hughes, L., Jamal, A., Jones, P., ... \& Rana, N. P. (2019). The impact of social media on consumer acculturation: Current challenges, opportunities, and an agenda for research and practice. International Journal of Information Management. DoI: https://doi.org/10.1016/j.ijinfomgt.2019.10.011

Kline, R.B. (2011). Principles and practice of structural equation modeling, (3rd. Ed.). New York: Guilford Press. 
Korsgaard, M. A., Schweiger, D. M., \& Sapienza, H. J. (1995). Building commitment, attachment, and trust in strategic decision-making teams: The role of procedural justice. Academy of Management journal, 38(1), 60-84..

Kumar N. (1996). The power of trust in manufacturer-retailer relationships. Harvard Business Review, November-December, 92-106.

Kumar, N., Scheer, L. K., \& Steenkamp, J. B. E. (1995). The effects of supplier fairness on vulnerable resellers. Journal of Marketing Research, 32(1), 54-65..

Lee, F. L. F., \& Chan, J. M. (2015). Digital media use and participation leadership in social protests: The case of Tiananmen commemoration in Hong Kong. Telematics \& Informatics, 32(4), 879-889.

Li, X, Hess TJ, Valacich JS. (2008). Why Do We Trust New Technology? A Study of Initial Trust Formation with Organizational Information Systems. Journal of Strategic Information Systems, 17, 39-71.

Luhmann, N. (1988). Familiarity, Confidence, Trust: Problems and Alternatives, in Trust, D. G. Gambetta (ed.), Basil Blackwell, New York, pp. 94-107.

Maslow, A.H. (1943). A theory of human motivation. Psychological Review, 50 (4), 370-96.

Mayer R, Davis J, Schooman F. (1995). An Integrative Model of Organizational Trust. Academy of Management Review, 20(3), 709-734.

McAlister AL, Perry CL, Parcel GS (2008). "How Individuals, Environments, and Health Behaviors Interact: Social Cognitive Theory". Health Behavior and Health Education: Theory, Research, and Practice (4th ed.). San Francisco, CA: John Wiley \& Sons, Inc. pp. 169-188.

McAllister, D.J. (1995). Affect-and cognition-based trust as foundations for interpersonal cooperation in organizations. Academy of Management Journal, 38(1), 24-59.

McKnight, D. H., Choudhury, V., \& Kacmar, C. (2002). Developing and validating trust measures for e-commerce: An integrative typology. Information Systems Research, 13(3), 334-359.

McClelland, D. (1988). Human Motivation. Cambridge University Press.

Mishra AK. (1995). Organizational response to crisis: the centrality of trust. In: Kramer RM, Tyler TR, editors. Trust in organizations. London, UK: Sage; p. 261-87.

Misirlis, N., \& Vlachopoulou, M. (2018). Social media metrics and analytics in marketing-S3M: A mapping literature review. International Journal of Information Management, 38(1), 270276.

Mitchell, A. A., \& Olson, J. C. (1981). Are product attribute beliefs the only mediator of advertising effects on brand attitude? Journal of Marketing Research, 18(3), 318-332. 
Molins-Ruano, P., Rodriguez, P. Atrio, S., \& Sacha, G. M., (2016), Modelling experts' behavior with e-valUAM to measure computer science skills," Computers in Human Behavior, vol. 61, 378-385.

Moorman, C., Deshpande, R., \& Zaltman, G. (1993). Factors affecting trust in market research relationships. Journal of Marketing, 57(1), 81-101..

Moorman C, Zaltman G, Deshpande R. (1992). Relationships between Providers and Users of Market Research: The Dynamics of Trust within and between Organizations. Journal of Marketing Research, 29(3), 314-328.

Morgan, R. M., \& Hunt, S. D. (1994). The commitment-trust theory of relationship marketing. Journal of Marketing, 58(3), 20-38.

Mowrer, O. H. (1960). Learning theory and the symbolic processes. Hoboken, NJ, US: John Wiley \& Sons Inc.

Mukherjee A, \& Nath P. (2003). A Model of Trust in Online Relationships Banking. International Journal of Bank Marketing, 21(1), 5-15.

Olanrewaju, A. S. T., Hossain, M. A., Whiteside, N., \& Mercieca, P. (2020). Social media and entrepreneurship research: A literature review. International Journal of Information Management, 50, 90-110.

Paik, H., \& Comstock, G. (1994). The effects of television violence on antisocial behavior: a meta-analysis1. Communication Research, 21(4), 516-546.

Pajares, Frank; Prestin, Abby; Chen, Jason; Nabi, Robin L (2009). "Social cognitive theory and media effects". The Sage Handbook of Media Processes and Effects: 283-297.

Pavlou, P. A. (2003). Consumer acceptance of electronic commerce: Integrating trust and risk with the technology acceptance model. International Journal of Electronic Commerce, 7(3), $101-134$..

Pennington, N. (2008). Will you be my friend: Facebook as a model for the evolution of the social penetration theory? Conference Papers-National Communication Association, 1.

Posey, C., Lowry, P. B., Roberts, T. L., \& Ellis, T. S. (2010). Proposing the online community self-disclosure model: The case of working professionals in France and the U.K. who use online communities. European Journal of Information Systems, 19(2), 181-195.

Riopelle, A.J. (1960). Observational learning of a position habit by monkeys. Journal of Comparative and Physiological Psychology, 53(5), 426-428.

Rogers, P. R., Miller, A., \& Judge, W. Q. (1999). Using information-processing theory to understand planning/performance relationships in the context of strategy. Strategic Management Journal, 20, 567-577. 
Rotter J-B. (1980). Interpersonal trust, trustworthiness, and gullibility. American-Psychologist $35(1), 1-7$.

Rose, R. and Wood, S. (2005). Paradox and the Consumption of Authenticity Through Reality Television. Journal of Consumer Research, 32(2), 284-296.

Rousseau DM, Sitkin SB, Burt RS, Camerer C. (1998). Not so different after all: a crossdiscipline view of trust. AMR, 23(3), 393-404.

Schaik, Carel P. van; Burkart, Judith M. (2011). Social learning and evolution: the cultural intelligence hypothesis. Philosophical Transactions of the Royal Society of London B: Biological Sciences. 366 (1567): 1008-1016.

Schurr, P. H., \& Ozanne, J. L. (1985). Influences on exchange processes: Buyers' preconceptions of a seller's trustworthiness and bargaining toughness. Journal of Consumer Research, 11(4), 939-953.

See-To, E. W. K., \& Ho, K. K. W. (2014). Value co-creation and purchase intention in social network sites: The role of electronic Word-of-Mouth and trust: A theoretical analysis. Computers in Human Behavior, 31, 182-189.

Shareef, M. A., Mukerji, B., Dwivedi, Y. K., Rana, N. P., \& Islam, R. (2019). Social media marketing: Comparative effect of advertisement sources. Journal of Retailing and Consumer Services, 46, 58-69.

Shareef, M. A., Mukerji, B., Alryalatc, M. A. A., Wright, A., \& Dwivedi, Y. K., (2018a) Advertisements on Facebook: Identifying the persuasive elements in the development of positive attitudes in consumers, Journal of Retailing and Consumer Services, 43, 258-268.

Shareef, M. A., Baabdullah, A., Dutta, S., Kumar, V, \& Dwivedi, Y. K., (2018b) Consumer adoption of mobile banking services: An empirical examination of factors according to adoption stages, Journal of Retailing and Consumer Services, 43, 54-67.

Shareef, M. A., Dwivedi, Y. K., Kumar, V., Davies, G., Rana, N. \& Baabdullah, A. (2018). Purchase intention in an electronic commerce environment: a trade-off between controlling measures and operational performance, Information Technology \& People, DoI: https://doi.org/10.1108/ITP-05-2018-0241.

Shareef, M. A., Dwivedi, Y. K., Kumar, V., \&, Kumar, U., (2016), Reformation of public service to meet citizens' needs as customers: Evaluating SMS as an alternative service delivery channel, Computers in Human Behavior, 61, 255-270.

Shareef, M. A., Archer, N., Fong, W., Rahman, M., \& Mann, I. J. (2013). Online Buying Behavior and Perceived Trustworthiness. British Journal of Applied Science \& Technology, 3(4), 662-683. 
Shareef, M. A. \& Kumar, V. (2012). Prevent/Control Identity Theft: Impact on Trust and Consumers' Purchase Intention in B2C EC. Information Resources Management Journal, 25(3), 30-60.

Shareef, M. A., Kumar, U., \& Kumar, V. (2008). Role of Different Electronic- Commerce (EC) Quality Factors on Purchase Decision: A Developing Country Perspective. Journal of Electronic Commerce Research, 9(2), 92-113.

Shin, D.-H. \& Park, S. (2019), 3D learning spaces and activities fostering users' learning, acceptance, and creativity. Journal of Computing in Higher Education, 31(1), 210-228.

Shin, D.-H. (2013), User experience in social commerce: in friends we trust, Behaviour \& Information Technology, 32 (1), 52-67.

Shin, D.-H. (2010), The effects of trust, security and privacy in social networking: a securitybased approach to understand the pattern of adoption. Interacting with Computers, 22, 5, pp. 428-138.

Shin, D.-H. (2009), Towards an understanding of the consumer acceptance of mobile wallet, Computers in Human Behavior 25 (6), 1343-1354.

Short J, Williams E, Christie B. (1976). The social psychology of telecommunications. London: Wiley.

Skinner, B. F. (1957). Verbal behavior. New York: Appleton-Century-Crofts.

Staples DS, Ratnasingham P. (1998). Trust: The Panacea of Virtual Management. Proceedings of the International Conference on Information Systems, 128-144.

Tajfel, H. (1982). Social psychology of intergroup relations. Annual Review of Psychology, 33, 1-39.

The Daily Star (2018, July 30), Reckless driving takes two young lives, Accessed in July 30, 2018.

Thibaut, N.; Kelley, H. (1959). The social psychology of groups. New York Wiley.

Thibaut, John; Kelley, Harold (2008).Social Exchange Theory. In Griffin, Em. A First Look at Communication Theory. McGraw Hill. pp. 196-205.

Tracy, S. J.; Tretheway, A. (2005). Fracturing the Real-Self-Fake-Self Dichotomy: Moving Toward "Crystallized Organizational Discourses and Identities. Communication Theory, 15 (2), 168-195.

Wang, X., Yu, C. 8c Wei, Y. (2012) Social media peer communication and impacts on purchase intentions: a consumer socialization framework, journal o f Interactive Marketing, 26, 4, pp. 198-208.

Williamson, O. E. (1993). Calculativeness, Trust, and Economic Organization. Journal of Law and Economics, 34, 453-502. 
Wu, J.-J., Chen, Y.-H. 8c Chung, Y.-S. (2010) Trust factors influencing virtual community members: a study of transaction communities, journal o f Business Research, 63, 9-10, pp. 1025-1032.

Zentall, Thomas R (2012). Perspectives on Observational Learning In Animals. Journal of Comparative Psychology, 126 (2), 114-128.

Zhang, C., Fan, C., Yao, W., Hu, X., \& Mostafavi, A. (2019). Social media for intelligent public information and warning in disasters: An interdisciplinary review. International Journal of Information Management, 49, 190-207.

Zucker, L. G. (1986). Production of Trust: Institutional Sources of Economic Structure, 18401920, in Research in Organizational Behavior (Volume 8), B. M. Staw and L. L. Cummings (eds.), JAI Press, Greenwich, CT, 1986, pp. 53-111.

\section{Appendix}

\section{Appendix A: Measuring Items for Independent and Dependent Variables of SMT Model}

\begin{tabular}{|c|c|c|}
\hline Construct & Items & Source \\
\hline $\begin{array}{l}\text { Dependability } \\
\text { (DD) }\end{array}$ & $\begin{array}{l}\text { 1. My demand can be fulfilled by the person who has posted the message } \\
\text { in our social media group } \\
\text { 2. I expect the person who has posted the message in our social media } \\
\text { group can meet my personal need } \\
\text { 3. The person who has posted the message in our social media group has } \\
\text { echoed my voice } \\
4 \text {. The message in our social media group has reflected my own desire } \\
\text { (Dropped) } \\
5 \text {. The message in our social media group can move forward my personal } \\
\text { desire which I could not raise }\end{array}$ & $\begin{array}{l}\text { Dwivedi et al., 2016; } \\
\text { Shareef et al., 2008/2011/; } \\
\text { Venkatesh et al. 2003/2012; } \\
\text { Authors self-developed }\end{array}$ \\
\hline $\begin{array}{l}\text { Fulfilled } \\
\text { Expectation } \\
\text { (FE) }\end{array}$ & $\begin{array}{l}\text { 6. The message posted in our social media group can contribute in social } \\
\text { desire } \\
7 \text {. Our society has demand for this type of opinion delivered through the } \\
\text { message posted in our social media group } \\
8 \text {. Societal needs can be fulfilled through this message posted in my social } \\
\text { media group } \\
\text { 9. I believe the message posted in our social media group has raised social } \\
\text { issue } \\
\text { 10. Society can be benefitted from the message posted in our social media } \\
\text { group }\end{array}$ & $\begin{array}{l}\text { Davis, 1989; Gefen et al., } \\
\text { 2003; Pavlou, 2003; Rogers, } \\
\text { 1995; Shareefet al., 2007; } \\
\text { Wolfinbarger \& Gilly, 2003 }\end{array}$ \\
\hline $\begin{array}{l}\text { Familiarity } \\
(\mathrm{FM})\end{array}$ & $\begin{array}{l}\text { 11. I know the person who has posted the message due to his/her interaction } \\
\text { in our social media group } \\
\text { 12. I can understand the person who has posted the message due to his/her } \\
\text { interaction in our social media group } \\
\text { 13. I have experience about the person who has posted the message due to } \\
\text { his/her interaction in our social media group } \\
\text { 14. We know each others who post message due to interaction in our social }\end{array}$ & $\begin{array}{l}\text { Dwivedi et al., 2016; 5; } \\
\text { Featherman \& Pavlou, 2003; } \\
\text { Shareef et al., } 2009\end{array}$ \\
\hline
\end{tabular}




\begin{tabular}{|c|c|c|}
\hline Construct & Items & Source \\
\hline & $\begin{array}{l}\text { media group (Dropped) } \\
15 . \quad \text { We share views on different social and commercial issues in our social } \\
\text { media group }\end{array}$ & \\
\hline Credibility (CR) & $\begin{array}{l}\text { 16. The person who has posted the message in our social media group has no } \\
\text { personal interest to gain from this information (Dropped) } \\
\text { 17. The person who has posted the message in our social media group has no } \\
\text { personal intention to gain from this information } \\
\text { 18. The person who has posted the message in our social media group has no } \\
\text { personal preoccupied motive to fabricate the true information } \\
\text { 19. I know the person who has posted the message in our social media group } \\
\text { is not biased } \\
20 \text {. The person who has posted the message in our social media group has no } \\
\text { personal commercial reason to post this message (Dropped) } \\
21 \text {. The person who has posted the message in our social media group has no } \\
\text { personal social reason to post this message }\end{array}$ & $\begin{array}{l}\text { Balasubramanianet al, 2003; } \\
\text { Collier \& Bienstock, 2006; } \\
\text { Fassnacht \& Koese, 2006; } \\
\text { Kumar et al., 2007; } \\
\text { Featherman et al., 2003; } \\
\text { Gefen et al., 2003; Liao et } \\
\text { al., 2011; Shareefet al., } \\
\text { 2009; Wangpipatwong et } \\
\text { al., 2005 }\end{array}$ \\
\hline $\begin{array}{l}\text { Predictability } \\
(\mathrm{PR})\end{array}$ & $\begin{array}{l}\text { 22. I am quite certain about what the person who has posted the message in } \\
\text { our social media group will do } \\
\text { 23. I am quite certain about what to expect from the person who has posted } \\
\text { the message in our social media group } \\
\text { 24. I know the person who has posted the message in our social media group } \\
\text { will behave as per my pre idea }\end{array}$ & $\begin{array}{l}\text { Featherman et al., 2003; } \\
\text { Featherman \&Pavlou, 2003; } \\
\text { Gefen et al., 2003; Liao et } \\
\text { al., 2011; Pavlou, 2003; } \\
\text { Shareef } \text { et al., 2008/2011 }\end{array}$ \\
\hline $\begin{array}{l}\text { Conformity } \\
(\mathrm{CN})\end{array}$ & $\begin{array}{l}\text { 25. I am quite certain that the person who has posted the message in our } \\
\text { social media group will uphold our group opinion } \\
\text { 26. I am quite certain that the person who has posted the message in our } \\
\text { social media group will maintain our group behavior } \\
\text { 27. I know the person who has posted the message in our social media group } \\
\text { will behave as expected } \\
\text { 28. I am quite certain that the person who has posted the message in our } \\
\text { social media group can represent our group } \\
\text { 29. I am quite certain that any message posted by any member of our group } \\
\text { will reflect our group characteristics }\end{array}$ & $\begin{array}{l}\text { Brewer, 1999; Ellsberg, } \\
\text { 1961; Featherman et al., } \\
\text { 2003; Featherman \& Pavlou, } \\
\text { 2003; Gudykunst et al., } \\
2001\end{array}$ \\
\hline Norms (NR) & $\begin{array}{l}\text { 30. The person who has posted the message in our social media group has } \\
\text { influence on me } \\
\text { 31. I feel a sense of sociability from the person who has posted the message } \\
\text { in our social media group } \\
\text { 32. I feel human warmth from the person who has posted the message in our } \\
\text { social media group } \\
\text { 33. I believe the person who has posted the message in our social media } \\
\text { group is important to me (Dropped) }\end{array}$ & $\begin{array}{l}\text { Chen, \&Thurmaier, 2005; } \\
\text { Collier \&Bienstock, 2006; } \\
\text { Devarajet al. 2002; Liao et } \\
\text { al., 2011; Parasuraman et } \\
\text { al., 2005; Shareef et al., } \\
\text { 2007; Shareef et al., 2009; } \\
\text { Wolfinbarger\&Gilly,2003 }\end{array}$ \\
\hline Monitor (MN) & $\begin{array}{l}\text { 34. I am connected with the person who has posted the message in our } \\
\text { social media group } \\
\text { 35. I am able to be connected with the person who has posted the message } \\
\text { in our social media group } \\
\text { 36. I have scope to be connected with the person who has posted the } \\
\text { message in our social media group through social presence } \\
\text { 37. I fee attachment with the person who has posted the message in our } \\
\text { social media group through social presence (Dropped) }\end{array}$ & 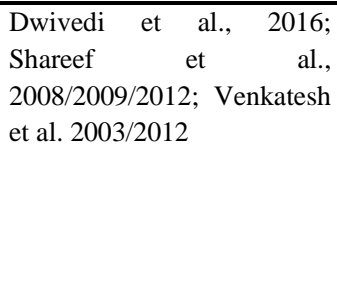 \\
\hline $\begin{array}{l}\text { Initial } \\
\text { (IT) }\end{array}$ & $\begin{array}{l}\text { 38. I have general faith on the person who has posted the message in our } \\
\text { social media group } \\
\text { 39. I can believe the person who has posted the message in our social media } \\
\text { group } \\
\text { 40. I have general confidence on the person who has posted the message in } \\
\text { our social media group }\end{array}$ & $\begin{array}{l}\text { Dwivedi et al., 2016; } \\
\text { Pavlou, 2003; Shareef e t al., } \\
2008\end{array}$ \\
\hline
\end{tabular}


